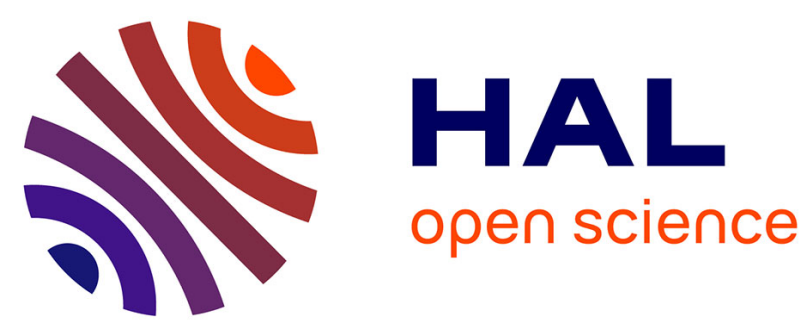

\title{
Brassica Ogu-INRA Cytoplasmic Male Sterility: An Example of Successful Plant Somatic Fusion for Hybrid Seed Production
}

Georges G. Pelletier, Francoise Budar

\section{- To cite this version:}

Georges G. Pelletier, Francoise Budar. Brassica Ogu-INRA Cytoplasmic Male Sterility: An Example of Successful Plant Somatic Fusion for Hybrid Seed Production. Somatic Genome Manipulation: Advances, Methods, and Applications, Chapter 9, Springer, pp.199-216, 2015, 978-1-4939-2388-5. 10.1007/978-1-4939-2389-2_9. hal-02793664

\section{HAL Id: hal-02793664 \\ https://hal.inrae.fr/hal-02793664}

Submitted on 5 Jun 2020

HAL is a multi-disciplinary open access archive for the deposit and dissemination of scientific research documents, whether they are published or not. The documents may come from teaching and research institutions in France or abroad, or from public or private research centers.
L'archive ouverte pluridisciplinaire HAL, est destinée au dépôt et à la diffusion de documents scientifiques de niveau recherche, publiés ou non, émanant des établissements d'enseignement et de recherche français ou étrangers, des laboratoires publics ou privés. 


\title{
Chapter 9
}

\section{Brassica Ogu-INRA Cytoplasmic Male Sterility: An Example of Successful Plant Somatic Fusion for Hybrid Seed Production}

\author{
Georges Pelletier and Francoise Budar
}

\subsection{Introduction}

The concept of hybrid vigor has gradually emerged since the eighteenth century when J.G. Koelreuter observed individual plants resulting from interspecific crosses in various genera, such as Nicotiana, Dianthus, Verbascum, Mirabilis, and Datura (Zirckle 1952). These observations were confirmed a century later by Darwin (1876) in vegetables, and by Beal (1880) in maize. In 1914, Schull coined the term "heterosis" to define this physiological state of vigor of plants produced from crosses between parental lines that originate from sufficiently different genetic pools (Schull 1952). Relatively high heterosis has been reported as a general feature of $\mathrm{F}_{1}$ hybrids in Brassica species: up to $80 \%$ higher seed production compared to the mid-parent value in winter oilseed rape (Brassica napus; Lefort-Buson and Dattée 1982), 90\% in Indian mustard (Brassica juncea; Pradhan et al. 1993), and $60 \%$ in summer turnip rape (Brassica rapa; Falk et al. 1994).

However, it is only relatively recently that breeders have been able to take advantage of heterosis for plant breeding. In the case of plants that reproduce by seed, obtaining large amounts of $F_{1}$ hybrid seed requires controlling cross-fertilization on a very large scale. The best way to do so is to grow large female stocks that will be pollinated by a male parent and harvest $\mathrm{F}_{1}$ seed from these stocks. Female stocks can be obtained mechanically in monoecious species and sometimes by chemical means in hermaphrodite species. However, the most efficient system involves maternally determined male sterility. Jones and Clarke described the first male-sterility system used for the production of hybrid varieties in onion (Allium cepa; Jones and Clarke 1943). In the following decades, similar systems were developed in a wide range of species such as sorghum (Sorghum bicolor), sugar beet (Beta vulgaris), corn (Zea mays), sunflower (Helianthus annuus), rice (Oryza sativa), carrot (Daucus carota), etc.

G. Pelletier $(\triangle) \cdot$ F. Budar

Institut Jean-Pierre Bourgin, INRA-AgroParisTech UMR 1318, Versailles, France

e-mail: Georges.Pelletier@versailles.inra.fr 
Studies on heterosis in Brassica have stimulated research on male-sterility systems, and they have greatly benefited from a wide range of biotechnological approaches such as interspecific/intergeneric crosses, in vitro culture, somatic hybridization, and genetic engineering. Only a few cases of spontaneous cytoplasmic male sterility (CMS) have been described in Brassica species: in B. rapa (Chinese cabbage; Okhawa and Shiga 1981) and in B. napus (rapeseed) with the "Polima" ( pol) system (Fu 1981) and the "Shaan 2A" (nap) system (Li 1986 communication in Chinese cited in Fu and Yang 1995).

The first CMS system described in an open-pollinated radish (Raphanus sativus) cultivar (Ogura 1968) has since been reported to be widespread in wild radish populations in Japan (Yamagishi and Terachi 1994a, 1996) and in Raphanus raphanistrum in Asia as well as in Europe (Yamagishi and Terachi 1997; Giancola et al. 2007). This CMS therefore predates the divergence between the two radish species.

\subsection{Somatic Hybridization in Brassicaceae for the Manipulation of Sex}

\subsubsection{Transfer of the Ogura Radish Sterility-inducing Cytoplasm into Brassica}

In 1974, Bannerot et al. introduced cytoplasmic male-sterile radish cytoplasm into Brassica oleracea (cabbage) using interspecific crosses and in vitro embryo culture (Bannerot et al. 1974; Yamagishi and Terachi 1994a, 1996), followed by several backcrosses with $B$. oleracea as the male parent until the $B$. oleracea genome (nine chromosomes) was stabilized in the Ogura radish cytoplasm (Fig. 9.1). Unfortunately, the resulting male-sterile plants with a complete Brassica genome in an Ogura radish cytoplasmic background showed chlorophyll deficiency, which was particularly expressed at low temperatures, and therefore rendered this combination unsuitable for commercial hybrid variety production (Fig. 9.2). Moreover, Brassica plants possessing this cytoplasm had underdeveloped nectaries, with reduced nectar production and malformed ovaries and pods (Fig. 9.3). Therefore, their flowers were not attractive to honeybees, the natural pollinators needed to ensure hybrid seed production. Female fertility, in terms of seed set, of these initial Ogura CMS $B$. oleracea plants was therefore reduced.

Furthermore, hybridization of these Ogura CMS $B$. oleracea plants with a $B$. napus male parent resulted, after cytoplasm transfer, in an Ogura CMS B. napus that showed the same range of defects (Pelletier et al. 1983). 
Fig. 9.1 An interspecific cross between an Ogura male-sterile radish with pollen of Brassica sp. followed by a series of backcrosses to Brassica, resulted in a male-sterile Brassica with Ogura radish plastids and mitochondria

Fig. 9.2 Chlorophyll deficiency $(\mathrm{Y})$ observed in Brassica plants with (Ogura) radish cytoplasm, compared to normal plants $(\mathrm{G})$

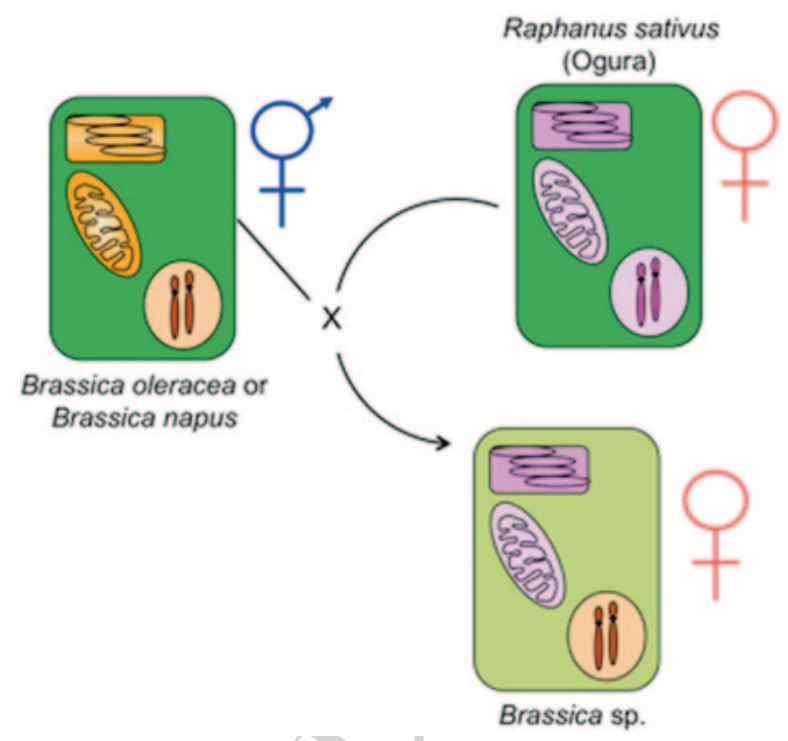

\subsubsection{Somatic Hybridization for Eliminating Ogura Cytoplasm Defects}

The defects in chloroplast biogenesis and floral morphology in Brassica plants with the Ogura cytoplasm were assumed to result from negative interactions between the Raphanus cytoplasm and the Brassica nucleus. For eliminating them, protoplasts 
Fig. 9.3 Malformed pods observed in Brassica plants with (Ogura) radish cytoplasm

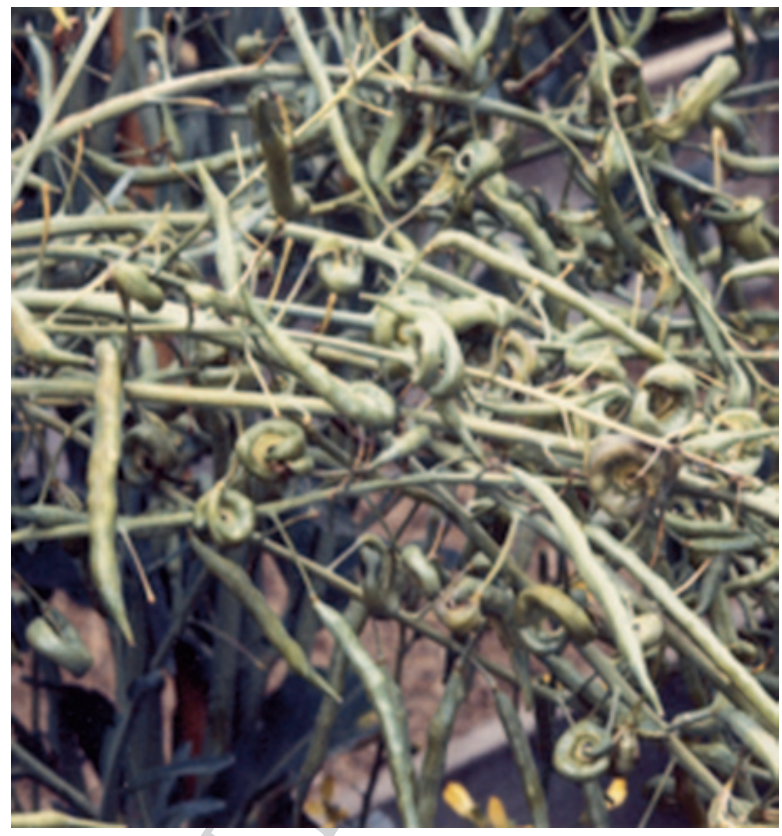

from a normal $B$. napus line (Table 9.1) were fused with protoplasts from a CMS (Ogura radish cytoplasm) B. napus, and protoplasts from a normal B. oleracea line were fused with protoplasts from a CMS (Ogura radish cytoplasm) B. oleracea in two independent experiments (Pelletier et al. 1983, 1988).

In parallel, an atrazine-resistant B. rapa (previously known as $B$. campestris) biotype was discovered in Canada (Maltais and Bouchard 1978). This resistance is encoded by plastid DNA. Alloplasmic B. napus lines with $B$. rapa atrazine-resistant cytoplasm have been produced and have shown to be fully resistant to the herbicide (Beversdorf et al. 1980). Material carrying this plastid marker trait was instrumental in protoplast fusion experiments for selecting cybrids that had successfully received this particular Brassica type of chloroplasts.

\subsubsection{Experimental Procedure for Brassica Protoplast Isolation and Fusion}

To isolate protoplasts for cybrid production, seeds of parental lines were surfacesterilized and then germinated in vitro. Shoot tip cultures were generated and cultured on the same medium (medium A, see Table 9.2) under a 16-h photoperiod, $150 \mu \mathrm{mol} . \mathrm{m}^{-2} \cdot \mathrm{s}^{-1}$ light intensity, and $24^{\circ} \mathrm{C}$, and repeatedly subcultured at 3-4-week intervals. Protoplasts were then isolated from scarified leaf fragments from these axenic in vitro plants by overnight maceration in $0.2 \%$ cellulase R10 and $0.1 \%$ 
Table 9.1 Recombination of cytoplasmic-associated traits in cybrids

\begin{tabular}{|c|c|c|c|c|}
\hline Genotype & Cytoplasm & Nucleus & $\begin{array}{l}\text { Parents of } \\
\text { the fusion }\end{array}$ & Associated traits \\
\hline 1 & B. napus & B. napus & - & $\begin{array}{l}\text { Male fertile, green leaves, normal } \\
\text { flowers, atrazine susceptible }\end{array}$ \\
\hline 2 & B. oleracea & B. oleracea & - & $\begin{array}{l}\text { Male fertile, green leaves, normal } \\
\text { flowers, atrazine susceptible }\end{array}$ \\
\hline 3 & B. rapa atr ${ }^{\mathrm{R}}$ & B. napus & - & $\begin{array}{l}\text { Male fertile, green leaves, normal } \\
\text { flowers, atrazine tolerant }\end{array}$ \\
\hline 4 & R. sativus & B. oleracea & - & $\begin{array}{l}\text { Male sterile, yellow leaves, abnormal } \\
\text { flowers, }{ }^{c} \text { atrazine susceptible }\end{array}$ \\
\hline 5 & Cybrid 58 & B. napus & $1+4^{b}$ & $\begin{array}{l}\text { Male sterile, green leaves, normal } \\
\text { flowers, atrazine susceptible }\end{array}$ \\
\hline 6 & Cybrid 17 & B. oleracea & $2+4$ & $\begin{array}{l}\text { Male sterile, green leaves, normal } \\
\text { flowers, atrazine susceptible }\end{array}$ \\
\hline 7 & Cybrid 77 & B. napus & $3+4$ & $\begin{array}{l}\text { Male sterile, green leaves, abnormal } \\
\text { flowers, atrazine tolerant }\end{array}$ \\
\hline 8 & Cybrid 13 & B. napus & $1+7$ & $\begin{array}{l}\text { Unstable male sterile, }{ }^{\mathrm{d}} \text { green leaves, } \\
\text { normal flowers, atrazine susceptible }\end{array}$ \\
\hline 9 & Cybrid 18 & B. napus & $1+7$ & $\begin{array}{l}\text { Unstable male fertile, }{ }^{\mathrm{d}} \text { green leaves, } \\
\text { normal flowers, atrazine tolerant }\end{array}$ \\
\hline
\end{tabular}

R. sativu, Raphanus sativus, B. napus, Brassica napus, B. oleracea Brassica oleracea, B. rapa atr ${ }^{\mathrm{R}}$ Brassica rapa atr ${ }^{\mathrm{R}}$

${ }^{\text {a }}$ When applicable

${ }^{\mathrm{b}}$ Numbers refer to column 1

${ }^{c}$ Abnormal flowers means no nectar and or malformed ovaries (see Fig. 9.3)

${ }^{\mathrm{d}}$ Cybrids 13 and 18 produced sexual progeny and somatic segregation of fully male-sterile and fully male-fertile plants, hence their phenotype was considered unstable

Table 9.2 The various media used in vitro for protoplast, tissue, and plant culture

\begin{tabular}{|c|c|}
\hline Medium & Composition \\
\hline A & $\begin{array}{l}\text { MS medium, } 10 \mathrm{~g} \cdot \mathrm{l}^{-1} \text { glucose, } 10 \mathrm{~g} \cdot \mathrm{l}^{-1} \text { sucrose, } 10 \mathrm{mg} \cdot \mathrm{l}^{-1} \text { gentamicin sulfate, } \\
8 \mathrm{~g} . \mathrm{l}^{-1} \text { agar }\end{array}$ \\
\hline B & $\begin{array}{l}\text { Gamborg (B5) medium, } 20 \mathrm{~g} . \mathrm{l}^{-1} \text { glucose, } 70 \mathrm{~g} . \mathrm{l}^{-1} \text { mannitol, } 1 \mathrm{mg} . \mathrm{l}^{-1} \mathrm{NAA}, \\
1 \mathrm{mg} .1^{-1} \text { BA, O.25 mg. } 1^{-1} \text { 2,4D, } 10 \mathrm{mg} . \mathrm{l}^{-1} \text { Tween } 80\end{array}$ \\
\hline $\mathrm{C}$ & $\begin{array}{l}\text { Half-strength B5 medium plus } 200 \mathrm{mg} . \mathrm{l}^{-1} \mathrm{NH}_{4} \mathrm{NO}_{3}, 20 \mathrm{~g} . \mathrm{l}^{-1} \text { sucrose, } 40 \mathrm{~g} . \mathrm{l}^{-1} \\
\text { mannitol, } 0.2 \mathrm{mg} . \mathrm{l}^{-1} \mathrm{NAA}, 1 \mathrm{mg} . \mathrm{l}^{-1} \mathrm{BA}\end{array}$ \\
\hline $\mathrm{D}$ & $\begin{array}{l}\text { Half-strength B5 macro salts, MS microelements, } 20 \mathrm{~g} . \mathrm{l}^{-1} \text { sucrose, } 1 \mathrm{mg} \cdot \mathrm{l}^{-1} \\
2,4 \mathrm{D}, 30 \mathrm{mg} \cdot \mathrm{l}^{-1} \text { adenine sulfate }\end{array}$ \\
\hline $\mathrm{E}$ & $\begin{array}{l}\text { MS medium, } 10 \mathrm{~g} .1^{-1} \text { sucrose, } 20 \mathrm{~g} . \mathrm{l}^{-1} \text { mannitol, } 1 \mathrm{mg} . \mathrm{l}^{-1} \mathrm{NAA}, 1 \mathrm{mg} \cdot \mathrm{l}^{-1} \mathrm{IPA} \text {, } \\
0.02 \mathrm{mg} . \mathrm{l}^{-1} \mathrm{GA} 3,8 \mathrm{~g} \cdot \mathrm{l}^{-1} \text { agarose }\end{array}$ \\
\hline $\mathrm{F}$ & MS medium, 10 g. $1^{-1}$ sucrose, $0.1 \mathrm{mg} . \mathrm{l}^{-1} \mathrm{NAA}, 0.5 \mathrm{mg} . \mathrm{l}^{-1} \mathrm{BA}, 8 \mathrm{~g} . \mathrm{l}^{-1}$ agarose \\
\hline G & $\begin{array}{l}\text { Half-strength MS medium, } 10 \mathrm{~g} . \mathrm{l}^{-1} \text { glucose, } 0.01 \mathrm{mg} \cdot \mathrm{l}^{-1} \mathrm{NAA}, 8 \mathrm{~g} . \mathrm{l}^{-1} \text { agar; } \mathrm{pH} \\
\text { adjusted to } 5.8 \text { before autoclaving }\end{array}$ \\
\hline
\end{tabular}

AS Murashige and Skoog 1962 B5; (Gamborg et al. 1968), $N A A_{\lambda}$ naphthalene acetic acid, $B A_{\lambda}$ benzyl aminopurine, 2,4-D 2,4-dichlorophenoxyacetic acid, $I P A_{\bar{\Omega}} \widehat{\mathrm{N}}^{6}-\left(\Delta^{2}\right.$ isopentenyl)-adenine, $G A_{3}$ gibberellic acid 
Fig. 9.4 a Brassica protoplast fusion, $\mathbf{b}$ cell colony formation, $\mathbf{c}$ derived callus with bud regeneration, and d bud growth into plantlets

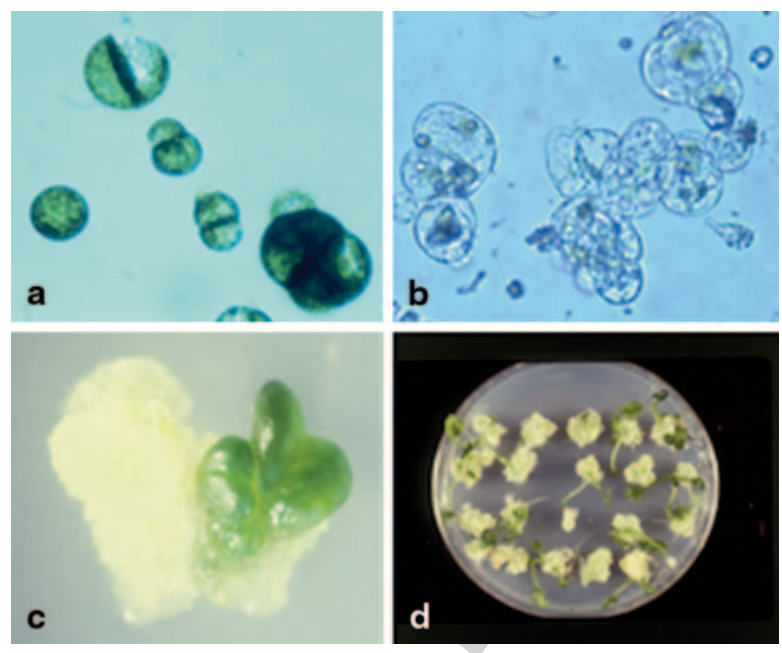

pectolyase $\mathrm{Y} 23$ in culture medium B (Table 9.2). After washing in $2.5 \% \mathrm{KCl}, 0.2 \%$ $\mathrm{CaCl}_{2} .2 \mathrm{H}_{2} \mathrm{O}$, protoplasts were fused (Fig. 9.4a) in drops of $25 \%$ polyethylene glycol 6000 in $3 \% \mathrm{CaCl}_{2} \cdot 2 \mathrm{H}_{2} \mathrm{O}$ and subsequently further diluted directly in the petri dish with culture medium $\mathrm{B}$ to a cell density of $5 \times 10^{4} \cdot \mathrm{ml}^{-1}$.

A succession of different media was used (shown in Table 9.2) to stimulate the growth of protoplast-formed colonies and bud regeneration (Fig. 9.4b c, d). Protoplasts were grown in the dark for 3 days after fusion and then transferred to an illuminated growth chamber, then diluted on day 12 with an equal volume of medium $\mathrm{C}$, and then with medium $\mathrm{D}$ on day 20 . On day 30 , colonies were plated onto medium $\mathrm{E}$ and emerging buds were placed onto medium F; after shoots developed, they were rooted on medium $\mathrm{G}$.

No nucleus or cytoplasm inactivation is needed before protoplast fusion because the purpose was not to obtain a new combination of nuclei and cytoplasm but to allow genetic recombination between the two species' cytoplasms, as discovered previously in Nicotiana tabacum (Belliard et al. 1978, 1979).

\subsubsection{Selection, Characterization, and Plastid Identification of Cybrids}

Selection was carried out on regenerated plants by screening for new combinations of cytoplasmic traits that resulted from fusion events, as described in Table 9.1. More specifically, from the combination by protoplast fusion of B. napus or B. oleracea cytoplasms with Ogura $R$. sativus cytoplasm, cybrids were selected to have not only normal greening of leaves at low temperature but also well-formed malesterile flowers. These cybrids were promising for developing male-sterile lines for $\mathrm{F}_{1}$ hybrid seed production. 
Raphanus and Brassica plastid DNAs are easily distinguished by their restriction patterns (Vedel et al. 1982; Yamagishi and Terachi 1997; Giancola et al. 2007) and the selected green, male-sterile plants contained only the B. napus, B. rapa, or B. oleracea chloroplast genomes (e.g., see cybrids 58, 17, 77 in Table 9.1). These results demonstrate that the chlorophyll deficiency in parental male-sterile Brassica lines was due to a detrimental interaction between Raphanus plastids and Brassica nuclei.

The plastid genomes of cybrids were identical to one parental genome in the case of B. napus/B. rapa cytoplasmic hybridization (e.g., cybrid 18 has B. rapa plastids and cybrid 13 has $B$. napus plastids; both were derived from the same fusion described in Table 9.1). Harboring one or the other parental plastid at random is a general feature of cybrid plants, indicating that the heteroplasmic state is very transitory. Nevertheless, in the cases where Ogura Raphanus plastids and Brassica plastids were combined by fusion in a Brassica nuclear background, the plastid type in recovered cybrids was always that of Brassica, indicating strong selection pressure against Ogura Raphanus plastids, which could result from the incompatible nucleo-plastid interaction observed in plant development (i.e., the dramatically reduced chlorophyll content).

The progeny of cybrids resulting from the combination of $B$. napus or B. oleracea cytoplasm with Ogura $R$. sativus cytoplasm shows complete stability of chloroplastic traits, i.e., normally green leaves and male sterility in subsequent sexual generations, indicating that the genetic determinants of the reverse traits (i.e., chlorophyll deficiency and male fertility) are lost after the cytoplasms are combined in protoplast fusion, and before the development of reproductive organs. Moreover, regarding flower morphology, abundant nectar production was recovered to some extent in cybrids 58 and 17 (and several others) but not in cybrid 77 (and several others), indicating that nectar production is not correlated with the plastid genome as is the case for leaf chlorophyll content.

Similar experiments on Ogura male sterility were performed by other laboratories in receipt of plant material obtained by Bannerot et al. in B. napus (Menczel et al. 1987; Jarl and Bornman 1988; Jarl et al. 1989;), B. oleracea (Kao et al. 1992; Walters et al. 1992; Walters and Earle 1993), and B. juncea (Kirti et al. 1995). When successful, these improved Ogura cytoplasms were introduced into other species such as B. rapa and B. juncea (Delourme et al. 1994) and vegetable B. rapa (Heath et al. 1994) via sexual crosses to produce male-sterile lines.

Protoplast fusions have also been used to transfer, or modify, other sterility-inducing cytoplasms into Brassica, such as the Kosena radish cytoplasm, subsequently shown to be a variant of the Ogura cytoplasm, in B. napus (Sakai and Imamura 1990, 1992), the "Anand" B. rapa cytoplasm in B. oleracea (Cardi and Earle 1997), the "polima" B. napus cytoplasm in B. oleracea (Yarrow et al. 1990), Diplotaxis muralis cytoplasm in B. juncea (Chatterjee et al. 1988), Moricandia arvensis cytoplasm in B. juncea (Prakash et al. 1998), and Brassica tournefortii cytoplasm in B. napus (Liu et al. 1995). 


\subsection{Molecular Analyses of Cybrid Mitochondrial Genomes}

\subsubsection{Mitochondrial Genomes of Cybrids}

Restriction profiles of cybrid and parental mitochondrial DNAs have been compared (Chetrit et al. 1985). As observed in tobacco, each cybrid profile is unique and different from those of the parents (except cybrid 77, which is apparently identical to the Ogura radish mitochondrial profile). In these restriction profiles, there are some parental restriction fragments and some new ones, a signature of molecular exchanges and recombination between the two parental genomes.

The fact that cybrid mitochondrial genomes are recombined is valuable in two ways. First, the male-sterile determinant originating from the Ogura radish can be segregated from undesirable traits that likely result from a detrimental interaction between radish mitochondria and Brassica nuclei, such as low nectar production and abnormal flower development. Second, it opened up the possibility of associating a specific DNA sequence with the male-sterile trait, this sequence being present in sterile cybrids and absent or modified in fertile ones. The molecular characterization of genomic fragments originating from the radish mitochondrial genome that were linked to undesirable traits, and the identification of the male-sterility mitochondrial gene (see below) allowed the definition and patenting of the Ogu-INRA system in Brassica crops.

\subsubsection{Identification of the Ogura CMS Gene}

CMS-associated genes are most often unconserved mitochondrial open reading frames (ORFs) created by intragenomic recombination (Hanson 1991; Braun et al. 1992; Kubo et al. 2011). They have a chimeric structure in which parts of normal mitochondrial genes can be recognized (Hanson and Bentolila 2004). The Brassicaceae family may be the one that has benefitted the most from efforts to identify mitochondrial male-sterility genes, because at least five different CMS systems have been studied at the molecular level: "Ogura" (Bonhomme et al. 1991), pol (L'Homme and Brown 1993), nap (L'Homme et al. 1997), tour (Landgren et al. 1996), and Mori (Ashutosh et al. 2008).

The mitochondrial determinant for Ogura-derived male sterility was one of the first CMS genes identified. It was discovered by studying Brassica cybrids obtained via the protoplast fusion experiments listed in Table 9.1. The first set of fusion experiments gave $B$. napus and $B$. oleracea cybrid cytotypes, which were used in a second series of fusion experiments involving cybrids and parental lines ("back-fusion"; Pelletier et al. 1986). Cybrid 13, derived from such an experiment, provided the material for the molecular characterization of the sterility determinant. This cybrid was selected as male-sterile, but it repeatedly reverted to male fertility 
with constant minor variation in mitochondrial DNA restriction profiles. It was therefore possible to correlate a mitochondrial DNA region with the male-sterile trait and a DNA sequence (orf138) whose expression at the RNA level is strictly correlated with the sterile phenotype of B. napus and B. oleracea cybrids (Bonhomme et al. 1991, 1992). Expression of this mitochondrial gene was subsequently associated with the sterile phenotype of the original "Ogura" radish (Krishnasamy and Makaroff 1993). Interestingly, orf125, a gene very similar to orf138, has been identified in the mitochondrial genome of the Kosena radish and assumed to be responsible for male sterility in this cytoplasm (Iwabuchi et al. 1999). Furthermore, Kosena CMS is very likely a variant form of Ogura CMS, and orf125 a sequence variant of orf138 (Koizuka et al. 2000; Yamagishi and Terachi, 2001).

\subsubsection{Contribution of New Recombined Genomic Arrangements to Our Understanding of Mitochondrial Gene Expression}

orfl 138 is a chimeric gene. The end of its coding sequence and the $3^{\prime}$ flanking region are identical (70 nucleotides including the last 12 codons) to the $3^{\prime}$ untranslated region of Arabidopsis thaliana orf557 (ccb206) that likely encodes a protein thought to be involved in cytochrome c biogenesis (Bellaoui et al. 1998). The B. napus orf577 gene, homologous to the bacterial ccll gene, is very similar to A. thaliana orf557 and has in its $3^{\prime}$ untranslated region the same short and perfect homology to orf138 (Menassa et al. 1997; Handa et al. 1996).

The orf 138 gene is co-transcribed with a gene called $\operatorname{orf} B$, conserved among plant mitochondrial genomes, and which has been demonstrated to correspond to the subunit 8 of the ATP synthase complex (Gray et al. 1998; Sabar et al. 2003). The bi-cistronic structure of the locus is responsible for the stability of the CMS trait in the Ogura radish and in stable cybrids. Instability has been observed in cybrids harboring a second copy of the $\operatorname{orf} B$ gene, introduced through back-fusion to normal $B$. napus and derived from the B. napus mitochondrial genome, or in cybrids in which the $\operatorname{orf} 138$ and $\operatorname{orf} B$ genes are no longer associated and the orf 138 gene is expressed as a monocistron, such as male-sterile plants derived from the unstable cybrid 18 (Bonhomme et al. 1991, 1992; Grelon et al. 1994; Bellaoui et al. 1998).

The unstable cybrid 13 not only helped identify the sterility gene but also shed light on the importance of posttranscriptional events such as degradation/stabilization of RNA in plant mitochondrial gene expression (Binder and Brennicke 2003). Indeed, in fertile revertants of cybrid 13 (13F plants), the orf 138 gene is present but found upstream of the atp $A$ gene instead of the $\operatorname{orf} B$ gene, due to recombination that deleted the Ogura radish $\operatorname{orf} B$ gene. As mentioned above, these plants carry a $B$. napus orfB gene, unlinked to orf 138 that compensated this loss. In this new genomic organization, the orf138 gene is no longer expressed (no detectable level of mRNA or protein), although it is transcribed as efficiently as in the sterile cybrid 13 plants because the transcript is rapidly degraded due to the lack of the stabilizing sequences found in the orfB 3' UTR (Bonhomme et al. 1992; Bellaoui et al. 1997). 
In contrast, male-sterile plants derived from cybrid 18, which carry a monocistronic orfl 138 with very efficient stabilizing sequences in its $3^{\prime} \mathrm{UTR}$, over-accumulate orf138 mRNA and the ORF138 protein (Grelon et al. 1994; Bellaoui et al. 1997).

The orf 125 gene from Kosena radish is present in the same genomic organization as the $\operatorname{orf1} 138$ gene and is co-transcribed with orfB (Iwabuchi et al. 1999). Iwabuchi et al. (1999) also described a monocistronic orf125 genomic organization in a sterile B. napus cybrid.

\subsubsection{Deciphering the Mechanism of CMS in Brassica Cybrids}

The ORF138 protein is bound to the inner mitochondrial membrane and forms oligomers (Grelon et al. 1994; Krishnasamy and Makaroff 1994; Duroc et al. 2005). It is present in all plant organs. In B. napus cybrids, its accumulation appears to follow the abundance of normal mitochondrial proteins in the different organs of the plant (Bellaoui et al. 1999). This result is not very surprising given that orf 138 expression is mediated by the promoter and posttranscriptional expression signals that drive the expression of the $\operatorname{orf} B$ gene, which encodes a subunit of the ATP synthase complex. However, as in many other CMS systems, it raises an intriguing question: Why is the phenotypic consequence of ORF138 accumulation restricted to pollen development?

In the tapetal cells of sterile anthers, mitochondria swell and lose their internal membrane structure at the tetrad stage (González-Melendi et al. 2008). This leads to premature degeneration of the tapetum and subsequent abortion of developing pollen. ORF138 forms an apparently homo-oligomeric complex in the inner membrane of mitochondria (Duroc et al. 2005, 2009). In contrast to what has been shown for G-CMS in beet (Ducos et al,, 2001), sunflower CMS (Sabar et al. 2003), and WACMS in rice (Luo et al. 2013), ORF138 does not interfere with complexes of the electron transport chain (Duroc et al. 2009). Nevertheless, measurements of oxygen consumption on whole anthers and on mitochondria isolated from buds suggested that mitochondria are partially uncoupled in sterile reproductive organs, whereas no sign of decoupling is detected in vegetative tissues (Duroc et al. 2009).

\subsection{The Restoration of Fertility in Ogura-related Systems}

\subsubsection{The Genetics of Restoration in Ogura and Ogu-INRA Plants}

Restorer genes are generally dominant, except for the unique homozygous lethal restorer rfll of maize, which was obtained by mutagenesis (Wen et al. 2003). Determinism is monogenic or oligogenic according to the male-sterility-inducing cytoplasm. In the case of the Ogura radish system, the genetics of restoration differs 
among crosses, suggesting that there are several redundant restoration loci in radish nuclear genotypes (Yamagishi and Terachi 1994b). In some cases, a single dominant restorer is sufficient to completely restore fertility of radish plants with the Ogura cytoplasm.

A restored B. napus has been obtained after crossing an alloplasmic rapeseed possessing the Ogura cytoplasm with a Raphano-brassica hybrid from an intergeneric cross, and subsequent chromosome doubling. The genetics of restoration in rapeseed carrying the unmodified Ogura cytoplasm is complex, involving several loci of which one is linked to a gene involved in petal color: white-flowered plants, a Raphanus-based character, were more fertile than yellow-flowered plants. Interestingly, the restoration of rapeseed cybrids with a corrected phenotype involves a unique locus, unlinked to petal color (Pelletier et al. 1986). The obtained restorer rapeseed genotypes show a unique radish introgression that carries the restoration locus, named Rfo (Delourme and Eber 1992; Delourme et al. 1998).

Two complementary genes were found to be necessary for restoring the Kosena radish CMS, whereas only one of them, named $R f k l$ or $R f k$, is sufficient for the restoration of $B$. napus cybrids (Koizuka et al. 2000). This gene was subsequently found to be identical to Rfo (see below).

\subsubsection{Effect of Restorer Nuclear Background on the Expression of the Ogura CMS Mitochondrial Gene}

In the vast majority of CMS systems, fertility restoration acts via the inhibition of male-sterility gene expression, most often at the RNA level, and sometimes at the protein level (Budar and Pelletier 2001; Budar et al. 2003). The influence of a restoration gene on the expression of a mitochondrial chimeric gene is sometimes the only evidence of the implication of this mitochondrial gene in the sterile phenotype (Kubo et al. 2011).

Nuclear restorers have a dramatic effect on the accumulation of the ORF138 protein in buds and leaves in Ogura radish (Krishnasamy and Makaroff 1994). In Ogu-INRA B. napus, restoration is characterized by the decrease of ORF138 accumulation in anthers and its complete depletion from the tapetum (Bellaoui et al. 1999; Uyttewaal et al. 2008). In both species, the accumulation of orf138 mRNA is not affected by the nuclear restorer gene indicating that the restorer acts either on mRNA translation efficiency or on ORF138 protein stability (Krishnasamy and Makaroff 1994; Bellaoui et al. 1999; Uyttewaal et al. 2008).

The orf 125 gene has an expression profile in Kosena CMS plants that is similar to that of the orf 138 gene in Ogura radish or Ogu-INRA Brassicas (Iwabuchi et al. 1999). In addition, as in the Ogura radish CMS or the Ogu-INRA Brassica cybrids, the restorer nuclear background induces a strong decrease in ORF125 protein accumulation, but does not affect the accumulation of orf 125 mRNA, either in Kosena radish or B. napus cybrids (Iwabuchi et al. 1999). 


\subsubsection{Identification of the Male-Fertility Restorer Gene}

$R f o$ and $R f k$, which are in fact the same gene, were independently identified by fine genetic mapping in radish (Brown et al. 2003; Desloire et al. 2003; Koizuka et al. 2003). This restorer gene encodes a pentatricopeptide repeat (PPR) protein which has been further characterized in a restored B. napus cybrid (Uyttewaal et al. 2008). The restoring protein interacts with orf $138 \mathrm{mRNA}$, and probably impairs its translation, thus preventing the deleterious effects of the ORF138 protein on tapetal cells.

\subsection{The Use of the Ogu-INRA Hybridization System for Seed Production in Brassica Crops}

Cabbage and rapeseed cybrids with the Ogura sterility determinant and corrected phenotypes have been evaluated in regard to their seed production and attractiveness to pollinators. These studies helped select two to three recombined cytoplasms in each crop, which were then provided to breeders in the early 1990 s.

In cabbage, only the vegetative parts of the plant are of agricultural interest; therefore, there was no need to introduce the restorer gene in hybrids. The first cabbage $F_{1}$ cultivars using the Ogu-INRA system were registered in the official French seed catalogue in 1993. They display $\sim 40 \%$ of heterosis, giving yields of around 200 tons per hectare (sauerkraut cabbage). In 1999, the French catalogue listed 65 $\mathrm{F}_{1}$ cultivars of different cabbage types that have been obtained using the Ogu-INRA CMS system.

The emergence of restored rapeseed hybrids was impaired by undesirable traits linked to the introgression of the radish $R f o$ gene, such as high glucosinolates, poor female fertility, and poor genetic stability of the restorer rapeseed genotypes. Nevertheless, cultivars containing a mixture of female hybrid plants and fertile plants from one of the parental lines in a $\sim 85: 15 \%$ ratio (line-hybrid composite, LHC) led to the registration of the first rapeseed hybrid cultivar (Synergy) in 1994. However, this type of cultivar may induce losses in yield when temperatures are unfavorable during the pollination period, which limits pollinator visits.

Considering the opposition of European authorities to transgenic rapeseed and the very high cost of complying with regulations, it is not possible to use restored genotypes in which only the radish $R$ fo gene has been introduced via transformation in Europe, even though this would eliminate all the developmental defects. This is an example of regulation inconsistencies and society's general attitude towards genetically modified organisms because the same gene (together with many other unknown genes) is already present in restored hybrid rapeseed cultivars with introgressed radish genes for male-fertility restoration.

An intense breeding effort to produce restorer lines has led to an improved R113 restorer line, followed by R2000 (Primard-Brisset et al. 2005). The first restored hybrid cultivar was authorized in 1999 in France. In 2002, 14\% of rapeseed crops 
were planted with restored hybrids versus $8 \%$ with LHC. The improvement of restorers has completely supplanted LHC cultivars. The introduction of a dwarf mutation in one of the hybrid parents allowed the development of half-dwarf hybrid cultivars in the mid-2000s.

Plant material has been distributed without exclusivity to a large number of seed companies in the world and license fees represent only a small percentage of the commercial price of seed. This material is widely used in Brassica vegetables, but much more in rapeseed. According to our calculations, in $2009,5.4 \times 10^{6}$ ha were planted with varieties containing the Ogu-INRA cytoplasm worldwide. Considering that the total rapeseed crop surface area of the main continents that use this system (Europe, North America, Australia) covers $\sim 15 \times 10^{6}$ ha, we estimate that the cytoplasms resulting from somatic hybridization are found in approximately one third of the rapeseed crops grown in these countries.

\subsection{Conclusion}

The main way of creating new CMS systems is to associate the nucleus of one species with the cytoplasm of a different origin, e.g., another species. This new association can be achieved either by crosses and backcrosses with the nuclear donor or by somatic cell genetics (cybrid production). The first method leads to several sources of CMS, which remain generally underexploited due to the multiple interactions between the cytoplasmic genes and the (foreign) nucleus with negative consequences on plant productivity. Cybrid production can result in improved CMS systems, due to plastid exchange and mitochondrial recombination.

More generally, in the absence of a method for transforming mitochondria in higher plants, the only possibility for manipulating the mitochondrial genome lies in cybrid production by protoplast fusion, which can be considered to be "cytoplasm breeding." This requires expertise in plant protoplast culture, which is becoming regrettably increasingly rare in today's plant biology laboratories.

Outside the family of Brassicaceae, examples of cybrid production for agricultural purposes can be found in tobacco (Horlow et al. 1993), rice (Akagi et al. 1995), or Citrus species (Bassene et al. 2008), illustrating how cellular and molecular biology can contribute significantly to plant breeding.

Acknowledgments We are very grateful to our colleagues at the INRA Rennes Center for their very impressive work on rapeseed breeding and for our long-running and very fruitful collaboration, particularly with Michel Renard and Régine Delourme. We acknowledge the excellent contributions of all colleagues and students involved in Versailles and Rennes INRA Centers who have worked for over 30 years on the Ogu-INRA CMS in Brassica. Our research on this CMS system has been partly funded by PROMOSOL, CETIOM, and Genoplante. We are also very grateful to Céline Duroc, joint head of the CETIOM technical center, for her help in retrieving data on the use of the Ogu-INRA system in agriculture. 


\section{References}

Akagi H, Taguchi T, Fujimura T (1995) Stable inheritance and expression of the CMS traits introduced by asymmetric protoplast fusion. Theor Appl Genet 91:563-567. doi:10.1007/ BF00223280

Ashutosh KP, Dinesh Kumar V, Sharma PC, Prakash S, Bhat SR (2008) A novel orf108 co-transcribed with the atpA gene is associated with cytoplasmic male sterility in Brassica juncea carrying Moricandia arvensis cytoplasm. Plant Cell Physiol 49:284-289. doi:10.1093/pcp/ pcm182

Bannerot H, Boulidard L, Cauderon Y, Tempé J (1974) Transfer of cytoplasmic male sterility from Raphanus sativus to Brassica oleracea. In:Eucarpia Meeting Cruciferae $p$ 52-54

Bassene J, Berti L, Carcouet E, Dhuique-Mayer C, Fanciullino AL, Bouffin J, Ollitrault P, Froelicher Y (2008) Influence of mitochondria origin on fruit quality in a citrus cybrid. J Agric Food Chem 56:8635-8640

Beal WJ (1880) Indian corn. Rept Michigan State Board_Agric_279-289.

Bellaoui M, Pelletier G, Budar $\widehat{F}$ (1997) The steady-state level of mRNA from the Ogura cytoplasmic male sterility locus in Brassica cybrids is determined post-transcriptionally by its $3^{\prime}$ region. EMBO J 16:5057-5068. doi:10.1093/emboj/16.16.5057

Bellaoui M, Martin-Canadell A, Pelletier G, Budar F (1998) Low-copy-number molecules are produced by recombination, actively maintained and can be amplified in the mitochondrial genome of Brassicaceae: relationship to reversion of the male sterile phenotype in some cybrids. Mol Gen Genet 257:177-185

Bellaoui M, Grelon M, Pelletier G, Budar F (1999) The restorer Rfo gene acts post-translationally on the stability of the ORF138 Ogura CMS-associated protein in reproductive tissues of rapeseed cybrids. Plant Mol Biol 40:893-902

Belliard G, Vedel F, Pelletier G (1979) Mitochondrial recombination in cytoplasmic hybrids of Nicotiana tabacum by protoplast fusion. Nature 281:401-403. doi:10.1038/281401a0

Beversdorf WD, Weiss-Lerman J, Erickson LR, Souza-Machado V (1980) Transfer of cytoplasmically inherited triazine resistance from birds-rape to cultivated oil seed rape (B. campestris and B. napus). Can J Genet Cytol 22:167-172

Binder S, Brennicke A (2003) Gene expression in plant mitochondria: transcriptional and posttranscriptional control. Philos Trans R Soc Lond, B, Biol Sci 358:181-8; discussion 188-9. doi:10.1098/rstb.2002.1179

Bonhomme S, Budar F, Férault M, Pelletier G (1991) A $2.5 \mathrm{~kb}$ NcoI fragment of Ogura radish mitochondrial DNA is correlated with cytoplasmic male-sterility in Brassica cybrids. Curr Genet 19:121-127. doi:10.1007/BF00326293

Bonhomme S, Budar F, Lancelin D, Small I, Defrance MC, Pelletier G (1992) Sequence and transcript analysis of the Nco2.5 Ogura-specific fragment correlated with cytoplasmic male sterility in Brassica cybrids. Mol Gen Genet 235:340-348

Braun CJ, Brown GG, Levings CSI (1992) Cytoplasmic male sterility. In: Hermann R (ed) Cell organelles. Plant Gene Research. Springer, New-York, pp 219-245

Brown GG, Formanová N, Jin H, Wargachuk R, Dendy C, Patil P, Laforest M, Zhang J, Cheung WY, Landry BS (2003) The radish Rfo restorer gene of Ogura cytoplasmic male sterility encodes a protein with multiple pentatricopeptide repeats. Plant J 35:262-272

Budar F, Pelletier G (2001) Male sterility in plants: occurrence, determinism, significance and use. C R Acad Sci III Sci Vie 324:543-550

Budar F, Touzet P, De Paepe R (2003) The nucleo-mitochondrial conflict in cytoplasmic male sterilities revisited. Genetica 117:3-16

Cardi T, Earle ED (1997) Production of new CMS Brassica oleracea by transfer of "Anand" cytoplasm from B. rapa through protoplast fusion. Theor Appl Genet 94:204-212

Chatterjee G, Sikdar SR, Das S, Sen SK (1988) Intergeneric somatic hybrid production through

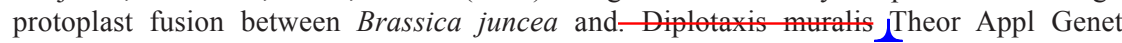
76:915-922 
Chetrit P, Mathieu C, Vedel F, Pelletier G, Primard C (1985) Mitochondrial DNA polymorphism induced by protoplast fusion in Cruciferae. Theor Appl Genet 69:361-366

Darwin C (1876) The effects of cross and self fertilisation in the vegetable kingdom. John Murray, London

Delourme R, Eber F (1992) Linkage between an isozyme marker and a restorer gene in radish cytoplasmic male sterility of rapeseed (Brassica napus L.). Theor Appl Genet 85:222-228. doi: 10.1007/BF00222863

Delourme R, Eber F, Renard M (1994) Transfer of radish cytoplasmic male sterility from Brassica

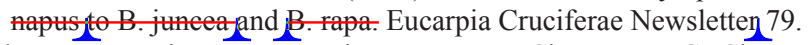

Delourme R, Foisset N, Horvais R, Barret P, Champagne G, Cheung WY, Landry BS, Renard M (1998) Characterisation of the radish introgression carrying the Rfo restorer gene for the Ogu-INRA cytoplasmic male sterility in rapeseed (Brassica napus L.). Theor Appl Genet 97:129-134

Desloire S, Gherbi H, Laloui W, Marhadour S, Clouet V, Cattolico L, Falentin C, Giancola S, Renard M, Budar F, Small I, Caboche M, Delourme R, Bendahmane A (2003) Identification of the fertility restoration locus, $\mathrm{Rfo}$, in radish, as a member of the pentatricopeptide-repeat protein family. EMBO Rep 4:588-594. doi:10.1038/sj.embor.embor848

Ducos E, Touzet P, Boutry M (2001) The male sterile G cytoplasm of wild beet displays modified mitochondrial respiratory complexes. Plant J 26:171-180

Duroc Y, Gaillard C, Hiard S, Defrance MC, Pelletier G, Budar F (2005) Biochemical and functional characterization of ORF138, a mitochondrial protein responsible for Ogura cytoplasmic male sterility in Brassiceae. Biochimie 87:1089-1100. doi:10.1016/j.biochi.2005.05.009

Duroc Y, Hiard S, Vrielynck N, Ragu S, Budar F (2009) The Ogura sterility-inducing protein forms a large complex without interfering with the oxidative phosphorylation components in rapeseed mitochondria. Plant Mol Biol 70:123-137. doi:10.1007/s11103-009-9461-6

Falk KC, Rakow G, Downey RK, Spurr DT (1994) Performance of inter-cultivar summer turnip rape hybrids in Saskatchewan. Can J Plant Sci 74:441-445

Fu D (1981) Production and research on rapeseed in the Peoples Republic in China. Eucarpia Cruciferae Newslett 6:6-7

Fu D, Yang GS (1995) Rapeseed heterosis breeding in China. In: 9th International Rapeseed Congress. Cambridge, pp 119-121

Gamborg OL, Miller RA, Ojima K (1968) Nutrient requirements of suspension cultures of soybean root cells. Exptl Cell Research 50:151-158

Giancola S, Rao Y, Chaillou S, Hiard S, Martin-Canadell A, Pelletier G, Budar F (2007) Cytoplasmic suppression of Ogura cytoplasmic male sterility in European natural populations of. Raphans raphanistror Appl Genet 114:1333-1343. doi:10.1007/s00122-007-0520-6

González-Melendi P, Uyttewaal M, Morcillo CN, Hernández Mora JR, Fajardo S, Budar F, Lucas MM (2008) A light and electron microscopy analysis of the events leading to male sterility in Ogu-INRA CMS of rapeseed (Brassica napus). J Exp Bot 59:827-838. doi:10.1093/jxb/ erm365

Gray MW, Lang BF, Cedergren R, Golding GB, Lemieux C, Sankoff D, Turmel M, Brossard N, Delage E, Littlejohn TG, Plante I, Rioux P, Saint-Louis D, Zhu Y, Burger G (1998) Genome structure and gene content in protist mitochondrial DNAs. Nucleic Acids Res 26:865-878

Grelon M, Budar F, Bonhomme S, Pelletier G (1994) Ogura cytoplasmic male-sterility (CMS)associated orf 138 is translated into a mitochondrial membrane polypeptide in male-sterile Brassica cybrids. Mol Gen Genet 243:540-547

Handa H, Bonnard G, Grienenberger JM (1996) The rapeseed mitochondrial gene encoding a homologue of the bacterial protein $\mathrm{Ccll}$ is divided into two independently transcribed reading frames. Mol Gen Genet 252:292-302

Hanson MR (1991) Plant mitochondrial mutations and male sterility. Annu Rev Genet 25:461-486. doi:10.1146/annurev.ge.25.120191.002333

Hanson MR, Bentolila S (2004) Interactions of mitochondrial and nuclear genes that affect male gametophyte development. Plant Cell 16(Suppl):154-169. doi:10.1105/tpc.015966 
Heath DW, Earle ED, Dickson MH (1994) Introgressing cold-tolerant Ogura cytoplasm from rapeseed into pak choi and Chinese cabbage. HortScience 29:202-203

Horlow C, Defrance MC, Pollien JM, Goujaud J, Delon R, Pelletier G (1993) Transfer of cytoplasmic male sterility by spontaneous androgenesis in tobacco (Nicotiana tabacum L.). Euphytica $66: 45-53$

Iwabuchi M, Koizuka N, Fujimoto H, Sakai T (1999) Identification and expression of the Kosena radish (Raphanus sativus cv. Kosena) homologue of the ogura radish CMS-associated gene, orf138. Plant Mol Biol 39:183-188

Jarl CI, Bornman CH (1988) Correction of chlorophyll_-defective, male - sterile winter oilseed rape (Brassica napus) through organelle exchange: phenotypic evaluation of progeny. Hereditas 108:97-102

Jarl CI, Grinsven MQJM, Mark F (1989) Correction of chlorophyll-defective male-sterile winter oilseed rape (Brassica napus) through organelle exchange: molecular analysis of the cytoplasm of parental lines and corrected progeny. Theor Appl Genet 77:135-141. doi:10.1007/ BF00292328

Jones HA, Clarke AE (1943) Inheritance of male sterility in the onion and the production of hybrid seed. Proc Amer Soc Hort Sci 43:189-194

Kao HM, Keller WA, Gleddie S, Brown GG (1992) Synthesis of Brassica oleracea/Brassica napus somatic hybrid plants with novel organeile DNA compositions. Theor Appl Genet 83:313-320

Kirti PB, Banga SS, Prakash S, Chopra VL (1995) Transfer of Ogu cytoplasmic male sterility to Brassica juncea and improvement of the male sterile line through somatic cell fusion. Theor Appl Genet 91:517-521

Koizuka N, Imai R, Iwabuchi M, Sakai T, Imamura J (2000) Genetic analysis of fertility restoration and accumulation of ORF125 mitochondrial protein in the Kosena radish (Raphanus sati$v u s \mathrm{cv}$. Kosena) and a Brassica napus restorer line. Theor Appl Genet 100:949-955

Koizuka N, Imai R, Fujimoto H, Hayakawa T, Kimura Y, Kohno-Murase J, Sakai T, Kawasaki S, Imamura J (2003) Genetic characterization of a pentatricopeptide repeat protein gene, orf687, that restores fertility in the cytoplasmic male-sterile Kosena radish. Plant J 34:407-415

Krishnasamy S, Makaroff C (1993) Characterization of the radish mitochondrial orfB locus: possible relationship with male sterility in Ogura radish. Curr Genet 24:156-163

Krishnasamy S, Makaroff CA (1994) Organ-specific reduction in the abundance of a mitochondrial protein accompanies fertility restoration in cytoplasmic male-sterile radish. Plant Mol Biol 26:935-946

Kubo T, Kitazaki K, Matsunaga M, Itchoda N, Estiati A, Mikami T (2011) Male sterility-inducing mitochondrial genomes: how do they differ? Crit Rev Plant Sci 30:378-400

Landgren M, Zetterstrand M, Sundberg E, Glimelius K (1996) Alloplasmic male-sterile Brassica lines containing B. tournefortii mitochondria express an ORF $3^{\prime}$ of the atp6 gene and a $32 \mathrm{kDa}$ protein. Plant Mol Biol 32:879-890

Lefort-Buson M, Dattée Y (1982) Genetic study of some agronomic characters in winter oilseed rape (Brassica napus L.) I Heterosis II genetic parameters. Agronomie 2:315-322

L'Homme Y, Brown GG (1993) Organizational differences between cytoplasmic male sterile and male fertile Brassica mitochondrial genomes are confined to a single transposed locus. Nucleic Acids Res 21:1903-1909

L'Homme Y, Stahl RJ, Li X-Q, Hameed A, Brown GG (1997) Brassica nap cytoplasmic male sterility is associated with expression of a mtDNA region containing a chimeric gene similar to the polCMS orf224gene. Curr Genet 31:321-335

Liu JH, Dixelius C, Eriksson I, Glimelius K (1995) Brassica napus $(+)$ B. tournefortii, a somatic hybrid containing traits of agronomic importance for rapeseed breeding. Plant Sci 109:75-86

Luo D, Xu H, Liu Z, Guo J, Li H, Chen L, Fang C, Zhang Q, Bai M, Yao N, Wu H, Wu H, Ji C, Zheng H, Chen Y, Ye S, Li X, Zhao X, Li R, Liu YG (2013) A detrimental mitochondrial-nuclear interaction causes cytoplasmic male sterility in rice. Nat Genet 45:573-577. doi:10.1038/ ng. 2570

Maltais B, Bouchard CJ (1978) Une moutarde des oiseaux (B. rapa) résistante à l'atrazine. Phytoprotection 59:117-119 
Menassa R, El-Rouby N, Brown GG (1997) An open reading frame for a protein involved in cytochrome e biogenesis is split into two parts in Brassica mitochondria. Curr Genet 31:70-79

Menczel L, Morgan A, Brown S, Maliga P (1987) Fusion-mediated combination of Ogura-type cytoplasmic male sterility with Brassica napus plastids using X-irradiated CMS protoplasts. Plant Cell Rep 6:98-101

Murashige T, Skoog F (1962) A revised medium for rapid growth and bioassays with tobacco tissue culture. Physiol Plant 15:473-497

Ogura H (1968) Studies on the new male sterility in Japanese radish, with special references to utilization of this sterility towards the practical raising of hybrid seeds. Mem Fac Agric Kagoshima Univ 6:39-78

Okhawa Y, Shiga T (1981) Possibility of hybrid seed production by use of cytoplasmic male sterility in Brassica campestris, Chinese cabbage. In: 1st Symp. Asian Veg. Res. Taiwan, pp 301-311

Pelletier G, Primard C, Vedel F, Chetrit P, Remy R, Rousselle P, Renard M (1983) Intergeneric cytoplasmic hybridization in Cruciferae by protoplast fusion. Mol Gen Genet 191:244-250

Pelletier G, Primard C, Vedel F, Chétrit P (1986) Genetic improvement of cytoplasmic traits through cytoplasmic hybridization in Crucifera. In: Horn W, Jensen CJ, Oldenbach W, Scheider O (eds) Genetic manipulation in plant breeding. Walter de Gruyter \& Co, Berlin, pp 653-661

Pelletier G, Primard C, Férault M, Vedel F, Chétrit P, Renard M, Delourme R (1988) Use of protoplasts in plant breeding: cytoplasmic aspects. Plant Cell Tiss Organ Cult 12:173-180

Pradhan AK, Sodhi YS, Mukhopadhyay A, Pental D (1993) Heterosis breeding in Indian mustard (Brassica juncea L. Czern \& Coss): analysis of component characters contributing to heterosis for yield. Euphytica 69:219-229. doi:10.1007/BF00022368

Prakash S, Kirti PB, Bhat SR, Gaikwad K, Kumar VD, Chopra VL (1998) A Moricandia arvensisbased cytoplasmic male sterility and fertility restoration system in. Brassica juncea Theor Appl Genet 97:488-492

Primard-Brisset C, Poupard JP, Horvais R, Eber F, Pelletier G, Renard M, Delourme R (2005) A new recombined double low restorer line for the Ogu-INRA cms in rapeseed (Brassica napus L.). Theor Appl Genet 111:736-746. doi:10.1007/s00122-005-2059-8

Sabar M, Gagliardi D, Balk J, Leaver CJ (2003) ORFB is a subunit of F1F(O)-ATP synthase: insight into the basis of cytoplasmic male sterility in sunflower. EMBO Rep 4:381-386. doi:10.1038/sj.embor.embor800

Sakai T, Imamura J (1990) Intergeneric transfer of cytoplasmic male sterility between Raphanus sativus (cms line) and Brassica napus through cytoplast-protoplast fusion. Theor Appl Genet 80:421-427

Sakai T, Imamura J (1992) Alteration of mitochondrial genomes containing atpA genes in the sexual progeny of cybrids between Raphanus sativus cms line and Brassica napus cv. Westar. Theor Appl Genet 84:923-929

Schull GH (1952) Beginnings of the heterosis concept. In: Gowen JW (ed) Heterosis. Iowa State College Press, Iowa, pp 1448

Uyttewaal M, Arnal N, Quadrado M, Martin-Canadell A, Vrielynck N, Hiard S, Gherbi H, Bendahmane A, Budar F, Mireau H (2008) Characterization of Raphanus sativus Pentatricopeptide repeat proteins encoded by the fertility restorer locus for Ogura cytoplasmic male sterility. Plant Cell 20:3331-3345. doi:10.1105/tpc.107.057208

Vedel F, Mathieu C, Lebacq P, Ambard-Bretteville F, Rémy R, Pelletier G, Renard M, Rousselle $\mathrm{P}$ (1982) Comparative macromolecular analysis of the cytoplasms of normal and cytoplasmic male sterile. B Theor Appl Genet 62:255-262. doi:10.1007/BF00276248

Walters TW, Earle ED (1993) Organellar segregation, rearrangement and recombination in protoplast fusion-derived Brassica oleracea calli. Theor Appl Genet 85:761-769. doi:10.1007/ BF00225017

Walters TW, Mutschler MA, Earle ED (1992) Protoplast fusion-derived Ogura male sterile cauliflower with cold tolerance. Plant Cell Rep 10:624-628

Wen L, Ruesch KL, Ortega VM, Kamps TL, Gabay-Laughnan S, Chase CD (2003) A nuclear restorer-of-fertility mutation disrupts accumulation of mitochondrial ATP synthase subunit alpha in developing pollen of S male-sterile maize. Genetics 165:771-779 
Yamagishi H, Terachi T (1994a) Molecular and biological studies on male -sterile cytoplasm in the Cruciferae. I. The origin and distribution of Ogura male-sterile cytoplasm in Japanese wild radishes (Raphanus sativus L.) revealed by PCR-aided assay of their mitochondrial DNAs. Theor Appl Genet 87:996-1000

Yamagishi H, Terachi T (1994b) Molecular and biological studies on male sterile cytoplasm in Cruciferae. II. The origin of Ogura male sterile cytoplasm inferred from the segregation pattern of male sterility in the F1 progeny of wild and cultivated radishes (Raphanus sativus L.). Euphytica 80:201-206. doi:10.1007/BF00039651

Yamagishi H, Terachi T (1996) Molecular and biological studies on male-sterile cytoplasm in the Cruciferae. III. Distribution of Ogura-type cytoplasm among Japanese wild radishes and Asian radish cultivars. Theor Appl Genet 93:325-332

Yamagishi H, Terachi T (1997) Molecular and biological studies on male-sterile cytoplasm in the Cruciferae. IV. Ogura-type cytoplasm found in the wild radish. ${ }_{\lambda}$ Raphanus raphanistrum Plant Breed 116:323-329

Yamagishi H, Terachi T (2001) Intra-and inter-specific variations in the mitochondrial gene orf138 of Ogura-type male-sterile cytoplasm from Raphanus sativus and. Raphanus raphanistrum Theor Appl Genet 103:725-732

Yarrow SA, Burnett LA, Wildeman RP, Kemble RJ (1990) The transfer of "Polima"cytoplasmic male sterility from oilseed rape (Brassica napus) to broccoli (B. oleracea) by protoplast fusion. Plant Cell Rep 9:185-188

Zirckle C (1952) Early ideas on inbreeding and crossbreeding. In: Gowen JW (ed) Heterosis. Iowa State College Press, Iowa, pp 1-13 
AQ1. "Belliard et al. 1978" is cited in the text but is not given in the reference list. Please provide a full reference, $\lambda$

AQ2. Please update the following references: "Bannerot et al. 1974" and "Delourme et al. 1994”,

AQ3. Please provide the volume details for reference "Beal $1880 "$, 